Vol 11, Issue 5, 2018

\title{
EVALUATION OF GENOTOXIC EFFECTS OF ALCOHOLIC EXTRACT OF KALANCHOE PINNATA USING SINGLE CELL GEL ELECTROPHORESIS
}

\author{
SARAVANAN V ${ }^{1 *}$, MURUGAN SS ${ }^{1,2}$, RAJKUMAR JSI ${ }^{2}$, NAVANEETHA KRISHNAN KR ${ }^{2}$ \\ ${ }^{1}$ Department of Biotechnology, Sathyabama University, Chennai, Tamil Nadu, India. ${ }^{2}$ GLR Laboratories Pvt Ltd., Mathur, Chennai, Tamil \\ Nadu, India. Email: siva.murugan@glrlabs.com
}

Received: 27 November 2017, Revised and Accepted: 18 January 2018

\section{ABSTRACT}

Objective: The objective of the study was to evaluate the genotoxic and mutagenic potentials of Kalanchoe pinnata alcoholic leaves extract.

Methods: Single cell gel electrophoresis (COMET assay) was adopted to investigate genotoxicity potential of standardized ethanolic leaves extract at the concentration of 10,50 , and $100 \mu \mathrm{g} / \mathrm{ml}$, respectively, using human lymphocytes.

Results: K. pinnata leaves extract did not completely damage DNA in human lymphocytes but low, medium, and high-level damage was found in with positive control. The DNA damage level decreases in low, medium, and high $(12 \pm 1,6 \pm 1$, and $1 \pm 1)$ without positive control at the concentration of 100 $\mu \mathrm{g} / \mathrm{ml}$.

Conclusion: It was concluded that the parent material did not induce mutagenic and genotoxic potentials at the concentrations 10,50 , and $100 \mu \mathrm{g} / \mathrm{ml}$ but its metabolites are inducing genotoxicity in various models.

Keywords: COMET, Ethanolic extract, Kalanchoe pinnata, Lymphocytes, Mutagenic.

(C) 2018 The Authors. Published by Innovare Academic Sciences Pvt Ltd. This is an open access article under the CC BY license (http://creativecommons. org/licenses/by/4. 0/) DOI: http://dx.doi.org/10.22159/ajpcr.2018.v11i5.23964

\section{INTRODUCTION}

Plants are considered as raw materials for alternative medicine and have antimutagenic effects against chemicals and environmental factors. On the other hand, these extracts may also have mutagenic effects on different organisms [1,2]. Medicinal plants are most important and commonly used in treatment for human diseases such as gastrointestinal disorders, cardiovascular disease, pain, diarrhea, fungal, and bacterial infections and cancer. The needs for reliable information on herbal medicinal products are considerable $[3,4]$. On the other hand, most of the traditional medicinal plants have never been the subject of exhaustive toxicological tests such as is required for modern pharmaceutical compounds. Based on their traditional use for long periods of time, they are often assumed to be safe. However, research has shown that many plants which are used as food ingredients or in traditional medicine have in vitro mutagenic or toxic and carcinogenic properties. Within this context, it is also important to screen medicinal plants for their mutagenic properties [5,6]. Kalanchoe pinnata (Family: Crassulaceae) commonly known as "Ranakalli" "Miracle leaf," "Wonder of the World." It is a perennial herb grows up to about 1-2 $\mathrm{m}$ tall containing a wide range of active compounds including triterpenes, alkaloids, glycosides, flavonoids, steroids, bufadienolide, and lipids. K. pinnata is an important plant which is largely used in folk medicine in India for the treatment of kidney stones, diabetes mellitus, and hypertension, wound healing, and diarrhea [7-10]. The aim of this study was to investigate the antimutagenic property of alcoholic extract of $K$. pinnata in human lymphocytes using single cell gel electrophoresis (SCGE) (COMET assay). Human lymphocytes are the standard model for individual eukaryotic cells that can be vitally evaluated cytologically by phase contrast and differential contrast microscopy. They can be assessed both cytochemically and biochemically for various perturbation affecting nuclear DNA including various form of DNA damage and repair [11]. In general, COMET assay is an economic, fast, sensitive, reliable, and rapid method. The SCGE/COMET assay combines the simplicity of biochemical techniques for detecting DNA single-strand breaks (frank strand breaks and incomplete excision repair sites), alkali-labile sites and cross-linking with the single cell approach typical of cytogenetic assays. This technique can be applied to proliferating and non-proliferating cells and the cells of those tissues, which are the first sites of contact with mutagens/carcinogens. What makes this assay even more valuable is the specificity for detecting genotoxicity. Like in other tests, DNA effects induced due to cytotoxicity is a big challenge. Data showed that cytotoxicity can be detected (dead cells show specific kinds of comets called "clouds") and distinguished from genotoxic effects, therefore, should have no confounding effects on results $[12,13]$.

\section{METHODS}

Fresh leaves of $K$. pinnata were collected from Thandarai village Chengalpattu, Kancheepuram district, Tamil Nadu, India. The plant material was authenticated by Dr. P. Jayaraman, Retired Professor, Department of Botany Presidency College, Chennai, Tamil Nadu, India, and Director Plant Anatomy Research Centre West Tambaram, Chennai, Tamil Nadu, India.

\section{Preparation of plant extracts}

Fresh leaves of $K$. pinnata were washed with sterile distilled water (Milli-Q) to remove any impurities present and were dried under the sunshade. The dried leaves were powdered in a motor and pistil followed by the extraction process. $100 \mathrm{~g}$ of powder was soaked in $600 \mathrm{ml}$ of ethanol and kept in a shaker for 7 days at $37^{\circ} \mathrm{C}$. After 7 days, the extract was filtered and dried on the hot plate [14]. A crude extract of $6 \mathrm{~g}$ was obtained. This extract was stored under aseptic conditions.

\section{SCGE (COMET assay)}

COMET assay was carried out with human blood lymphocytes. The glass slides were coated with normal melting agarose (NMA) by dipping the slide into melted NMA, and the slide was wiped clearly on one side with sterile absorbent cotton. The slide was then allowed to dry overnight. 3 milliliters of heparinized whole blood was mixed with $3 \mathrm{ml}$ of RPMI 1640 medium. To this $3 \mathrm{ml}$ of lymphocyte separation medium 
(LSM) was added to the centrifuge tube. The diluted $3 \mathrm{ml}$ blood sample was carefully layered on LSM so that the sample did not mix up with LSM. It was then centrifuged at $400 \mathrm{RPM}$ for $30-40 \mathrm{~min}$ at $20^{\circ} \mathrm{C}$. The upper layer of the centrifuged sample was drawn using a clean, sterile micropipette, leaving the lymphocyte layer undisturbed at the interface. The cell viability was counted and checked with Trypan blue staining method. The cells that exceed $90 \%$ viability were used in genotoxicity assay. $0.9 \mathrm{ml}$ of the cell suspension was mixed with $0.1 \mathrm{ml}$ of $K$. pinnata extract at the concentration of 10,50 , and $100 \mu \mathrm{g} / \mathrm{ml}$ and incubated at $37^{\circ} \mathrm{C}$ for $30 \mathrm{~min}$. The cells were then collected by centrifugation. The cell suspension $(100 \mu \mathrm{l})$ was mixed with $200 \mu \mathrm{l}$ of $1 \%$ low melting point agarose prepared in phosphate buffer saline and was immediately pipetted onto a $1 \%$ NMA in distilled water pre-coated, and the slide was dried overnight. The slide was placed at $4^{\circ} \mathrm{C}$ for $10 \mathrm{~min}$ to get solidified. Over this agarose layer melting agarose was added as the third layer and the slides were kept at $4^{\circ} \mathrm{C}$ for $10 \mathrm{~min}$ and allowed to complete the polymerization of agarose and immersed in freshly made lysis solution (2.5 M-Nacl, $100 \mathrm{mM}$-EDTA, $10 \mathrm{mM}$ Tris $\mathrm{HCl}, 10 \%$ dimethyl sulfoxide, $1 \%$ Triton X-100 pH-10) at room temperature for $2 \mathrm{~h}$ to remove cellular proteins. The slides were then rinsed with distilled water and placed in a horizontal gel electrophoresis containing buffer $(300 \mathrm{mM} \mathrm{NaOH}, 1$ $\mathrm{mM}$ EDTA at pH-13) and the electrophoresis was started at 25V, $200 \mathrm{~mA}$ for $20 \mathrm{~min}$. The slides were washed 2 times for $5 \mathrm{~min}$ with $0.4 \mathrm{M}$ Tris $\mathrm{HCl}-\mathrm{pH}-7.4$ at $4^{\circ} \mathrm{C}$. After second neutralization, the slides were dried and stained with Ethidium Bromide $(10 \mu \mathrm{g} / \mathrm{ml})$ and examined using a fluorescent microscope. A total of 100 cells from each of the two replicate slides were examined per sample. Using computerized image analysis system, the data were analyzed. By the ratio of tail to head length the extent of DNA damages was scored as follows: $<5 \%$ - no damage, 5-20\% low damage, 21-40\% medium damage, 41-95\% high damage, and $>95 \%$ complete damage [15-18].

\section{RESULTS AND DISCUSSION}

At the concentration $10 \mu \mathrm{g} / \mathrm{ml}, 53 \pm 1$ cells were found to have no damage; low damage was found in $31 \pm 1$ and medium damage was found in $9 \pm 1$. K. pinnata extract caused high damage in $7 \pm 1$ cells. At the concentration $50 \mu \mathrm{g} / \mathrm{ml}, 60 \pm 2$ cells were found to have no damage; low damage was found to be in $28 \pm 1$, and medium damage was found in $10 \pm 3$. K. pinnata extract caused high damage in $2 \pm 0$ cells. At the concentration $100 \mu \mathrm{g} / \mathrm{ml}, 43 \pm 3$ cells were found to have no damage; low damage was found to be in $46 \pm 3$, and medium damage was found in $8 \pm 3$. $K$. pinnata extract caused high damage in $3 \pm 1$ cells. The results are shown in Table 1 and Fig. 1.

The leaf extracts showed DNA damage with positive control. Hence, $100 \mu \mathrm{g} / \mathrm{ml}$ of leaf extract was selected for secondary comet assay. Two trials of comet assay were conducted without positive control. At the concentration $100 \mu \mathrm{g} / \mathrm{ml}, \mathrm{A} 80 \pm 3$ cells were found to have no damage; low damage was recorded in $12 \pm 1$ and medium damage was observed in $6 \pm 1$. $K$. pinnata extract caused high damage in $2 \pm 1$ cells. At the concentration $100 \mu \mathrm{g} / \mathrm{ml}, \mathrm{B} 79 \pm 10$ cells were found to have no damage; low damage was recorded in $17 \pm 6$ and medium damage was observed in $3 \pm 1$. K. pinnata extract caused high damage in $1 \pm 1$ cells. The results are shown in Table 2 and Figs. 2 and 3.

Medicinal plants are used for home remedies and are widely used in developed and developing countries. They are a diverse source of nutrients and bioactive compounds that are valuable for human health. Many ethanobotanical surveys and traditional knowledge of medicinal plant have been proved their significance in curing various diseases [19]. Therefore, it is necessary to do tests to evaluate their quality and quantity of exposure. Medicinal plants have become popular during the years, but there is limited knowledge about the safety and effectiveness of medicinal properties and their usage by physicians, and some evidence demonstrate that these medicinal plants can be dangerous [20]. This study was performed to investigate the genotoxicity of alcoholic extract of K. pinnata in human blood lymphocytes. Many plant species express genotoxic activities with the incidence of tumors; therefore, the understanding of the potential toxicity of medicinal plants is highly important. Photochemical present in some traditional medicinal plants are potentially carcinogenic and may have genotoxic potentials.

K. pinnata contain photochemical such as triterpenes, alkaloids, glycosides, flavonoids, steroids, and bufadienolide [21,22]. Genotoxicity studies on K. pinnata extract in human lymphocytes were assessed by SCGE (COMET assay) are a very sensitive test for the quantification of DNA damage and provides the direct determination of single-double strand breaks in individual cells. Cells were treated with hydrogen peroxide as positive control and different concentration of $K$. pinnata extract $(10-100 \mu \mathrm{g} / \mathrm{ml})$ results showed that there was low, medium, and high damage at concentration $10-100 \mu \mathrm{g} / \mathrm{ml}$ in preliminary comet assay it may be due to difference in cell physiology like cell cycle [23-27]. The K. pinnata extracts showed DNA damage with positive control. In secondary comet assay, two trials were conducted without positive control at the concentration $100 \mu \mathrm{g} / \mathrm{ml}$. Results showed that there was a decrease in cell damage compared with the preliminary COMET assay with positive control. On the other hand, another study revealed that the ethanolic extracts of $K$. pinnata show significant wound healing potential. K. pinnata extracts showed DNA damage in a dose-dependent manner with COMET assay. K. pinnata is medicinal plant, traditionally used in the treatment of several diseases showed no complete DNA damage with COMET assay. This confirms original parent molecule is not genotoxic in nature, but its metabolites are producing genotoxicity in various models. All though it possess the antimutagenic property and it requires further investigation.

\section{CONCLUSION}

$K$. pinnata is Indian traditional medicinal plant it contains various phytochemical widely used in siddha, Ayurveda and folk medicine

Table 1: Genotoxicity of ethanolic extract of $K$. pinnata in human lymphocyte in the COMET assay with positive control

\begin{tabular}{lllllll}
\hline Sample & Concentration $(\mu \mathrm{g} / \mathbf{m l})$ & No & Low & Med & High & Compl. \\
\hline K. pinnata extract & 10 & $53 \pm 1$ & $31 \pm 1$ & $9 \pm 1$ & $7 \pm 1$ & 0 \\
& 50 & $60 \pm 2$ & $28 \pm 1$ & $10 \pm 3$ & $2 \pm 0$ & 0 \\
Positive control & 100 & $43 \pm 3$ & $46 \pm 3$ & $8 \pm 3$ & $3 \pm 1$ & 0 \\
Negative control (blank) & & $55 \pm 1$ & $32 \pm 1$ & $9 \pm 2$ & $2 \pm 2$ & $2 \pm 1$ \\
\hline
\end{tabular}

No: No damage, Low: Low damage, Med: Medium damage, High: High damage, Compl: Complete damage, K. pinnata: Kalanchoe pinnata

Table 2: Genotoxicity of ethanolic extract of $K$. pinnata in human lymphocyte in the confirmatory comet assay without positive control

\begin{tabular}{lllllll}
\hline Sample & Concentration & No & Low & Med & High & Compl. \\
\hline K. pinnata extract & $100 \mu \mathrm{g} / \mathrm{ml} \mathrm{A}$ & $80 \pm 3$ & $12 \pm 1$ & $6 \pm 1$ & $2 \pm 1$ & 0 \\
Negative control & $100 \mu \mathrm{g} / \mathrm{ml} \mathrm{B}$ & $79 \pm 10$ & $17 \pm 6$ & $3 \pm 1$ & $1 \pm 1$ & 0 \\
\hline
\end{tabular}

No: No damage, Low: Low damage, Med: Medium damage, High: High damage, Compl: Complete damage, K. pinnata: Kalanchoe pinnata 


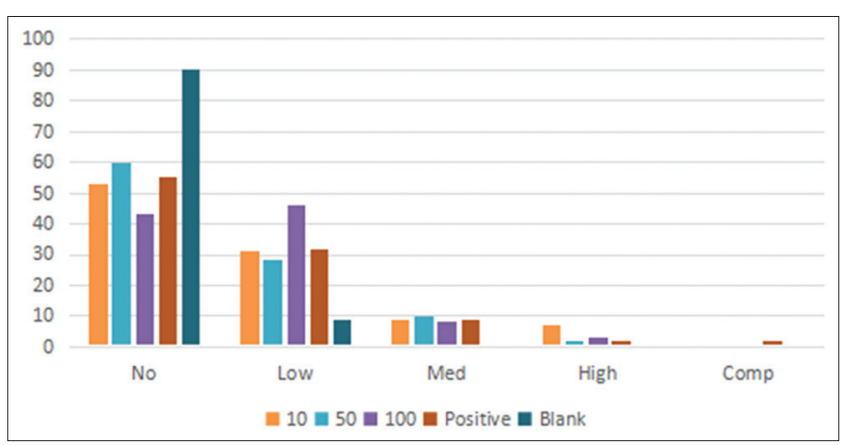

Fig. 1: Distribution of cells in various DNA damage categories for leaf extracts with positive control

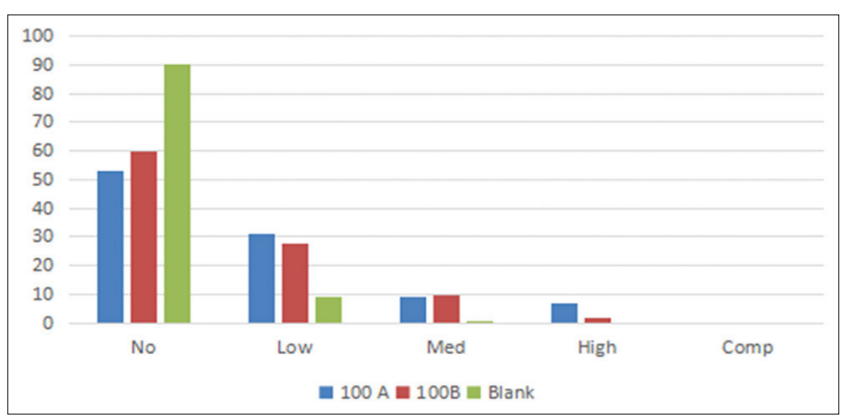

Fig. 2: Distribution of cells in various DNA damage categories for leaf extracts without positive control

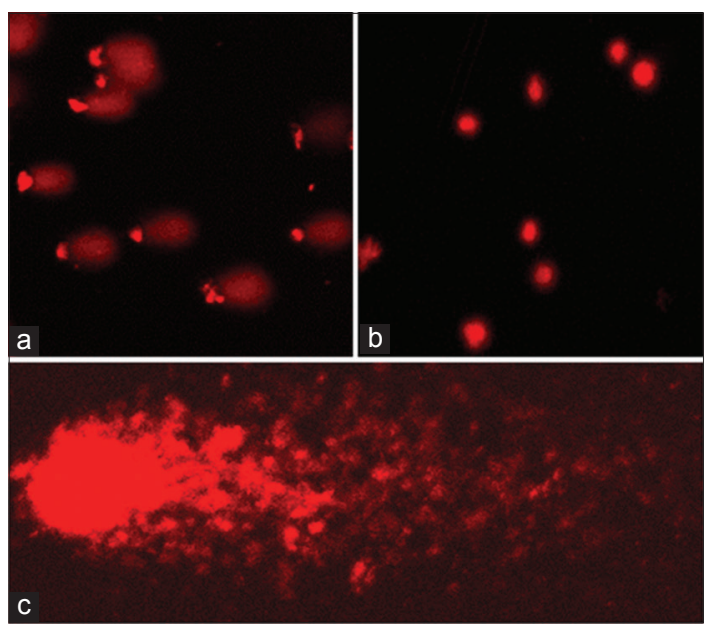

Fig. 3: Photomicrographs of stained DNA of human lymphocyte for alkaline COMET assay. (a) Treated with Kalanchoe pinnata extract $(100 \mu \mathrm{g} / \mathrm{ml})$ showing DNA damage in COMET tail. (b) Untreated showing no DNA damage, (c) Tail moment

for the treatment of various diseases such as diabetes mellitus, kidney stones, and wound healing. In this study design to examine the genotoxic effects of alcoholic extract of $K$. pinnata at various concentration using SCGE (COMET assay). These results suggest that alcoholic extract of $K$. pinnata showed DNA damage at low, medium, and high level. However, no complete DNA damage was observed in both preliminary and secondary comet assay at all the concentration using human lymphocytes. These indicate the original parent molecule is not mutagenic, but its metabolites are producing mutagenic.

\section{CONFLICTS OF INTEREST}

The authors declare that there are no conflicts of interest.

\section{REFERENCES}

1. Erena Y, Ozatab A. Determination of mutagenic and cytotoxic effects of Limonium globuliferum aqueous extracts by Allium, Ames, and MTT tests. Braz J Pharm 2014;24:51-9.

2. Tsuboy MS, Marcarini JC, Luiz RC, Barros IB, Ferreira DT, Ribeiro LR, Mantovani MS. In vitro evaluation of the genotoxic activity and apoptosis induction of the extracts of roots and leaves from the medicinal plant Coccoloba mollis (Polygonaceae). J Medi Food 2010;13:503-8.

3. Almostady AA, Mutwakil MH, ElAssouli MZ, Ahmed MM, El Assouli SM. Genotoxicity and antigenotoxicity activites of Rhazya stricta and Zingiber officinale single and in combination. Am Eur J Agric Environ Sci 2015;15:1392-401.

4. Chaudhary M, Payasi A. Evaluation of genotoxicity of trois through Ames and in vitro chromosomal aberration tests. Asian Pac J Trop Biomed 2013;3:902-6.

5. Wesam RK, Ghanya AN, Mizaton HH, Ilham M, Aishah A. Assessment of genotoxicity and cytotoxicity of standardized aqueous extract from leaves of Erythroxylum cuneatum in human hepG2 and WRL68 cells line. Asian Pac J Trop Med 2013;6:811-6.

6. Guez CM, Waczuk EP, Pereira KB, Morini Quero MV, Teixeira da Rocha JB, Souza de Oliveira LF. In vivo and in vitro genotoxicity studies of aqueous extract of Xanthium spinosum. Braz J Pharma Sci 2012;48:461-7.

7. Rajsekhar PB, Arvind Bharani RS, Ramachandran M, Angel KJ, Vardhini Rajsekhar SP. The "Wonder Plant" Kalanchoe pinnata (Linn.) Pers.: A Review. J Appl Pharma Sci 2016;6:151-8.

8. Majaz AQ, Tatiya AU, Khurshid M, Shaiih Siraj SN. The miracle plant (Kalanchoe pinnata) A phytochemical and pharmacological review. Int J Res Ayurveda Pharm 2011;2:1478-82.

9. Mahata S, Maru S, Shukla S, Pandey A, Mugesh G, Das BC, et al. Anticancer property of Bryophyllum pinnata (Lam.) Oken. Leaf on human cervical cancer cells. BMC Complement Altern Med 2012;12:15.

10. Hsieh YJ, Leu YL, Chang CJ. The anti-cancer activity of Kalanchoe tubiflora. OA Alter Medi 2013;1:1-4.

11. Wasiti EA, Whab Shaban SA, Salihi AR, Aubaidy HA. Evaluating the levels of oxidative DNA damage in human lymphocytes in response to caffeine using comet assay (Single Cell Gel Electrophoresis). Int J Pharm Pharm Sci 2016;8:137-41

12. Langie SA, Azqueta A, Collins AR. The comet assay past, present and future. Front Genet 2015;6:1-3.

13. Collins AR. The comet assay: A heavenly method. Mutagenesis 2015;30:1-4

14. Azwanida NN. A review on extraction methods use in medicinal plants, principle, strength and limitation. Med Aroma Plants 2015;4:1-6.

15. Santos CL, Pourrut B, Ferreirade Oliveira JM. The use of comet assay in plant toxicology: Recent advances. Front Genet 2015;6:1-18.

16. Tice RR, Agurell E, Anderson D, Burlinson B, Hartmann A, Kobayashi $\mathrm{H}$, et al. Single cell gel/comet assay: Guidelines for in vitro and in vivo genetic toxicology testing environmental and molecular. Mutagenesis 2000;35:206-21.

17. Nandhakumar S, Parasuraman S, Shanmugam MM, Rao KR, Chand P, Bhat BV. Evaluation of DNA damage using single-cell gel electrophoresis (Comet Assay). J Pharm Pharm 2011;2:107-11.

18. Mattana CM, Cangiano MA, Alcaraz LE, Sosa A, Escobar F, Sabini C, et al. Evaluation of cytotoxicity and genotoxicity of Acacia aroma leaf extracts. Sci World J 2014;2014:1-6.

19. Attar UA, Ghane SG. Phytochemicals, antioxidant activity and phenolic profiling of Diplocyclos Palmatus (L.) C. Jeffery. Int J Pharm Pharm Sci 2017;9:101-6.

20. Kalantari H, Rezaei M, Salehcheh M, Moosavi M, Varnaser G. Determination of the mutagenicity potential of dillsun herbal medicine by single cell gel electrophoresis in rat hepatocytes. Jund J Nat Pharma Prod 2013;8:55-9.

21. Menon N, Sparks J, Omoruyi F. Hypoglycemic and hypocholesterolemic activities of the aqueous preparation of Kalanchoe pinnata leaves in streptozotocin induced diabetic rats. Asian Pac J Trop Biomed 2015;5:3-9.

22. Ahmed Chowdhury KA, Huq ME, Ali S, Huq I, Royhan MJ, Kabir I, et al. Antioxidant, cytotoxic and thrombolytic activity of leaves of Kalanchoe pinnata (LAM.) PERS. J Pharm Phytochem 2016;5:309-15.

23. Leffa DD, da Rosa R, Munhoz BP, Martins Mello AA, Mandelli FD, Amaral PA, et al. Genotoxic and antigenotoxic properties of Calendula officinalis extracts in mice treated with methyl methanesulfonate. Adv Life Sci 2012;2:21-8. 
24. Saleem U, Mahmood S, Ahmad B, Saleem M, Anjum AA. Estimation of genotoxic and mutagenic potential of latex and methanolic leaves extract of Euphorbia helioscopia by comet assay and Ames test. Asian Pac J Trop Dis 2015;5:145-50.

25. Srividya AR, Dhanbal SP, Sathish Kumar MN, Vishnuvarthan VJ. Comparison of geotoxixity produced by hydro alcoholic extracts of Curcuma aromatica Salisb, Curcuma zedoaria with Curcumin by ames test comet assay micronucleous assay. Int Res J Pharm 2013;4:113-9.

26. Ping KY, Darah I, Chen Y, Sasidharan S. Cytotoxicity and genotoxicity assessment of Euphorbia hirta in MCF-7 cell line model using comet assay. Asian Pac J Trop Biomed 2013;3:692-6.

27. Lin H, Guo X, Zhang S, Dial SL, Guo L, Manjanatha MG, et al. Mechanistic evaluation of Ginkgo biloba leaf extract-induced genotoxicity in L5178Y Cells. Toxi Sci 2014;139:338-49. 